\title{
Effect of low-temperature annealings on mechanical properties and evolution of nanostructured alloy $\mathrm{Zr1Nb}$
}

\author{
V.I.Sokolenko, E.V.Karaseva, A.V.Mats, E.S.Savchuk, V.A.Frolov \\ National Science Center "Kharkiv Institute of Physics and Technology", \\ 1 Akademicheskaya Str., 61108 Kharkiv, Ukraine
}

\section{Received February 2, 2017}

\begin{abstract}
The processes of internal stresses relaxation in $\mathrm{Zr1Nb}$ nanocrystalline alloy after lowtemperature annealing were studied. The relationship of structural states obtained as a result of annealings with the regularities of development of plastic deformation at creep was established. It is shown that heat treatments of Zr1Nb nanostructured alloy, which provide the increase of the plasticity, change qualitatively the alloy structure, destruct the nanostructured state that results in decrease of the mechanical characteristics of the material and the degree of resistance to subsequent deformation during the creep at the temperature of $700 \mathrm{~K}$.
\end{abstract}

Keywords: nanostructure, creep, heat treatments, structural instability.

\begin{abstract}
Исследованы процессы релаксации внутренних напряжений в нанокристаллическом сплаве Zr1Nb после низкотемпературных отжигов. Установлена взаимосвязь структурных состояний, полученных в результате отжигов, с закономерностями развития пластической деформации при ползучести. Показано, что термообработки наноструктурированного сплава Zr1Nb, которые обеспечивают повышение пластичности, качественно изменяют структуру сплава, разрушая наноструктурное состояние, что приводит к снижению механических характеристик и степени устойчивости материала к последующей деформации в процессе ползучести при температуре $700 \mathrm{~K}$.
\end{abstract}

Вплив низькотемпературного відпалу на механічні властивості та еволюцію наноструктури сплава Zr1Nb. В.І.Соколенко, Є.В.Карасьова, О.В.Мац, С.С.Савчук, В.О.Фролов.

Досліджено процеси релаксації внутрішніх напружень у нанокристалічному сплаві Zr1Nb після низькотемпературних відпалів. Встановлено взаємозв'язок структурних станів, отриманих в результаті відпалу, із закономірностями розвитку пластичної деформації при повзучості. Показано, що термообробки наноструктурованого сплаву Zr1Nb, які забезпечують підвищення пластичності, якісно змінюють структуру сплаву, руйнуючи наноструктурний стан, що призводить до зниження механічних характеристик і ступеня стійкості матеріалу до наступної деформації у процесі повзучості при температурі $700 \mathrm{~K}$.

\section{Introduction}

Recently polycrystalline nanostructured materials $(d<100 \mathrm{~nm})$ are intensively created and investigated. The interest of investigators to these materials is defined by their unique mechanical and physical-chemical properties, which are differ significantly from the corresponding for polycrystals with fine $(d<10 \mathrm{~mm})$ and coarse $(d>$ $10 \mathrm{~mm}$ ) grains [1-4]. There are some promising methods of the bulk metallic nanomaterials creating by intensive plastic deformation (IPD): rolling, equal channel angular pressing, torsion under high pressure, allround compression $[1,4]$ etc. These materi- 


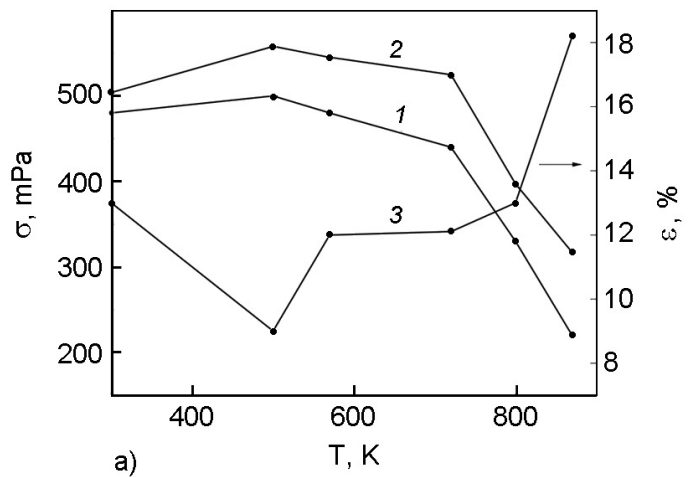

a)

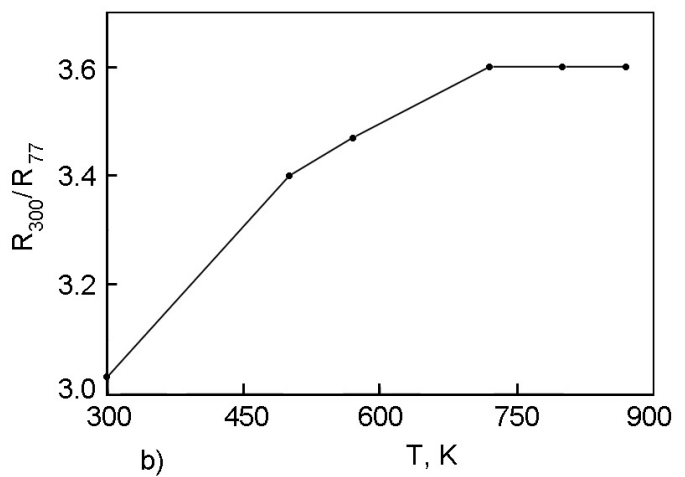

b)

Fig. 1. Dependenceц of the yield strength $\left(\sigma_{0.2}\right)(1 \mathrm{a})$, tensile strength $\left(\sigma_{B}\right)(2 \mathrm{a})$, plasticity $(\varepsilon)(3 \mathrm{a})$ and relative resistivity $\left(R_{300 \mathrm{~K}} / R_{77 \mathrm{~K}}\right)(\mathrm{b})$ of nanostructured alloy $\mathrm{Zr1Nb}$ deformed at $700 \mathrm{~K}$ under creep conditions on the pre-annealing temperature.

als, created by IPD, are characterized by the high internal stresses, which complicates the production of subjects from such materials without intermediate heat treatments, the effectiveness of which, in terms of relieving stresses, increases with increasing the temperature. However, probability of the substantial grain coarsening increases with increasing the annealing temperature, that can leads to the loss of the advantage of the nanocrystalline state. In the conditions of high internal stresses in such materials the grain growth begins at the lower temperatures. In particular, the temperature of recrystallization start in nanomaterials is significantly lower than the normal temperature of the starting of recrystallization in pure metals $(\sim 0.4-$ $0.5 T_{m}$ ) [5], and amount to $0.28 \sim T-T_{m}$ 0.35 [6]. In addition, the recrystallization in nanomaterials occurs at high rate: the rate of the grains growth reaches $10^{-5} \mathrm{~cm} / \mathrm{sec}$, and the activation energy of the grain growth is significantly lower than the activation energy of the processes grain-boundary self-diffusion [7].

Therefore, research on establishment of the relationship of structure-phase state nanomaterials obtained by annealing with the laws of plastic deformation of the creep in the temperature range below $0.5 T_{p}$, is very important. This will allow, on the one hand - to develop understanding of the mechanisms of deformation at the low temperature creep, and on the other - to set up the boundaries of practical use and possibility of further improving the properties of nanocrystalline metallic materials obtained by the methods of IPD.

\section{Experimental}

The investigated material was the polycrystalline alloy $\mathrm{Zr} 1 \mathrm{Nb}$ obtained by electron beam melting. With the purpose to influence on the structure and properties of the alloy $\mathrm{Zr} 1 \mathrm{Nb}$ the thermomechanical treatments were conducted in vacuum in the following modes:

1. MT-1 - combined rolling at 77-300 K, the residual deformation $(\varepsilon)$ was 3.9 ;

2. MTT-1 - MT- 1 + annealing at $500 \mathrm{~K}, 1 \mathrm{~h}$; 3. MTT-2 - MT-1 + annealing at $570 \mathrm{~K}, 1 \mathrm{~h}$; 4. MTT-3 - MT-1 + annealing at $720 \mathrm{~K}, 1 \mathrm{~h}$; 5. MTT- 4 - MT- 1 + annealing at $800 \mathrm{~K}, 1 \mathrm{~h}$; 6. MTT-5 - MT-1 + annealing at $870 \mathrm{~K}, 1 \mathrm{~h}$. The methods of measuring of electrical resistance after each treatment and in the process of creep were used for study of defect structure of the materials. Electrical resistance was measured at $T=300 \mathrm{~K}$ for 4th point scheme by compensative method. The measuring error did not exceed $+0.05 \%$, and variation of values of specific electrical resistance did not exceed $\pm+0.5 \%$. Monitoring the structure evolution was carried out by electron microscopy.

Creep tests were carried out in the step loading regime, the measurement accuracy of elongation was $5 \cdot 10^{-5} \mathrm{~cm}$.

\section{Results and discussion}

The characteristics of creep of Zr1Nb alloy samples after various treatments were examined in the temperature range of 300$700 \mathrm{~K}$. The strength characteristics (yield strength, tensile strength and plasticity) and the relative resistivity of the alloy $\mathrm{Zr} 1 \mathrm{Nb}$ depending on the heat treatment temperature are shown in Fig. 1. 


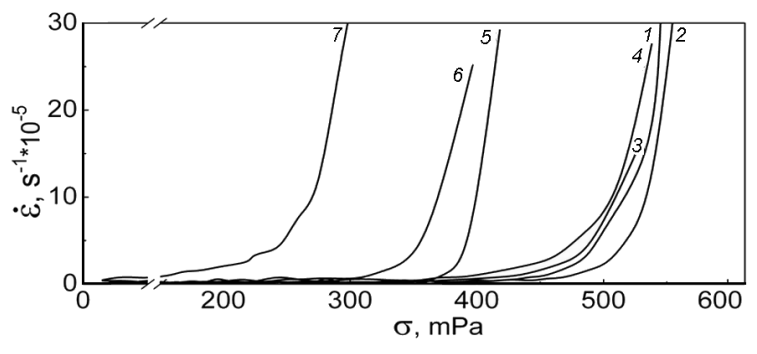

Fig. 2. Dependences of creep rate of nanostructured alloy $\mathrm{Zr} 1 \mathrm{Nb}$ at $700 \mathrm{~K}$ on the applied stress: 1 - MT-1; 2 - MTT-1; 3 MTT-2; 4 - MTT-3; 5 - MTT-4; 6 - MTT-5.

Fig. 2 shows the dependences of the creep rate at $700 \mathrm{~K}$ (operating temperature of reactors) of the alloy samples after all treatments over the entire range of stresses.

Analysis of the experimental data is shown that annealing at temperatures of 500-720 K does not substantially change the strength properties of the material; the plasticity and the creep rate do not increase. At the same time there is constant increase in the relative resistivity with increasing the annealing temperature from $500 \mathrm{~K}$ to $720 \mathrm{~K}$ (Fig. 1b), indicating the decrease of internal stresses level and can be associated with the redistribution or decreasing of the defects overall level in the material.

It should be noted, that after annealing at $500 \mathrm{~K}$ the low hardening effect of the alloy $\mathrm{Zr} 1 \mathrm{Nb}$ is observed. Similar effect was observed after annealing in the temperature range before recrystallisation in other metals [5-7]. Since during annealing the substructure of the nanomaterials tend not formed, the traditional points of view can not be used for explaining the effect. The assumptions were made in the works [1, 57] about the relationship the hardening effect in the nanostructure metals after annealing in the temperature range before re- crystallisation with the processes of formation of impurity atmospheres around dislocations, the peculiarities interaction of the grain boundaries with impurities with accumulation of defects in the migrating grain boundaries of the metals, in which the rate of migration under the conditions of abnormal grain growth significantly exceeds the rate of migration of the grain boundaries in the conditions of collective recrystallization. It is also known that the temperature of the beginning of the dynamic effect of aging for the alloy $\mathrm{Zr} 1 \mathrm{Nb}$ is about $\sim 400 \mathrm{~K}$ and at the same temperature, the maximum of diffusion mobility of oxygen atoms is observed [8-10]. However, the question of the hardening mechanisms is open until now and requires detailed experimental studies and construct of corresponding physical models.

Further increase in the annealing temperature $T>720 \mathrm{~K}$ leads to decrease of strength properties and to increasing of plasticity. At this time the relative electrical resistivity does not change (Fig. 1b). This means that the overall level of defects in the structure does not change, and the decrease of mechanical characteristics may be associated with the restructuring and ordering of the structure of Zr1Nb alloy [11].

Electron microscopic images of the structures of the alloy $\mathrm{Zr} 1 \mathrm{Nb}$ after different treatments are presented in Fig. 3.

The structure investigations are shown that after the combined rolling of $\mathrm{Zr} 1 \mathrm{Nb}$ alloy on the value of true strain $\varepsilon \sim 3.9$ the nanostructure with the grain size of $\sim 60 \mathrm{~nm}$ is formed (Fig. 3a). The dislocation density in the grains body is about $\sim 3.4 \cdot 10^{10} \mathrm{~cm}^{-2}$. Most of the dislocations are concentrated at the grain boundaries and triple junctions. The average size of disorientation, caused by boundaries, is about $\sim 6^{\circ}$. At the same time there are big concentrations of the high angle boundaries $\left(8-30^{\circ}\right)$, as well as the ragged
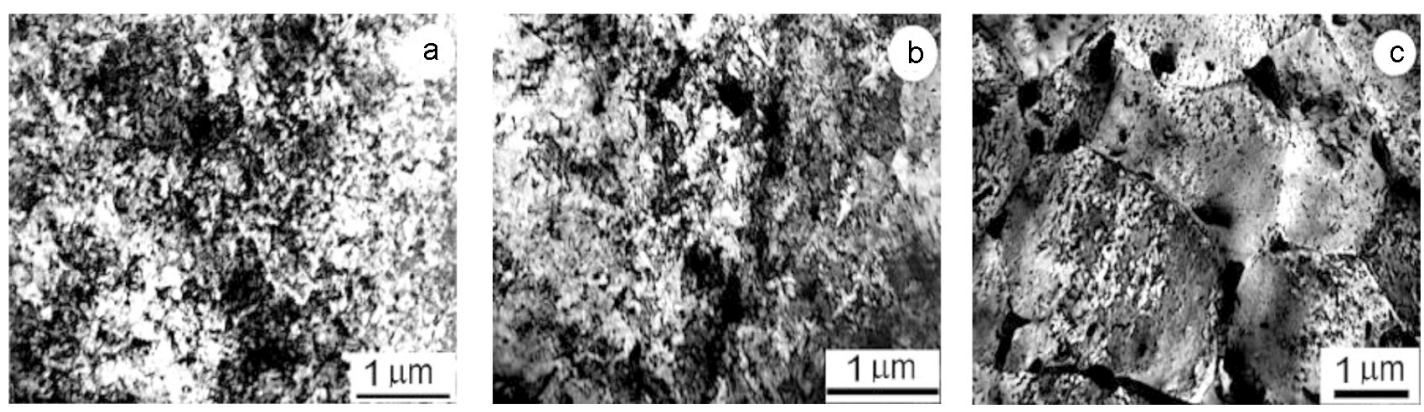

Fig. 3. TEM images of Zr1Nb alloy after the following treatments: a) MT-1; b) MTT-4; c) MTT-5. 

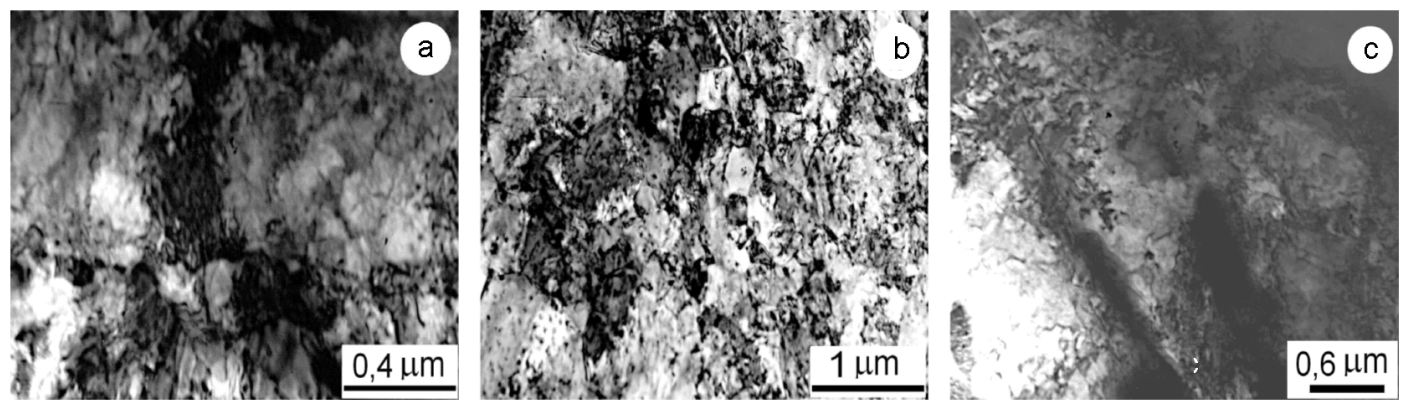

Fig. 4. TEM images of Zr1Nb alloy after the following treatment: a) MT-1 + creep at $700 \mathrm{~K}$ $\left(\sigma \approx 0.9 \sigma_{B}\right)$; b) MTT-4 + creep at $700 \mathrm{~K}\left(\sigma \approx 0.9 \sigma_{B}\right) ;$ c) MTT-5 + creep at $700 \mathrm{~K}\left(\sigma \approx 0.9 \sigma_{B}\right)$.

dislocation boundaries. Sharp heterogeneity of contrast on the electron microscopic images testifies of the high level of internal stresses and presence of the peak stresses in the boundaries junctions.

Annealings in the temperature range of $500-870 \mathrm{~K}$ leads to the internal stress relaxation and transformation of the nanostructures with the increasing intensity.

Annealing the nanostructured alloy $\mathrm{Zr} 1 \mathrm{Nb}$ in the temperature range of $500-570 \mathrm{~K}$ does not cause the significant change in the character of the microstructure. All the peculiar properties of the microstructure, which are characteristic for the nanostructured state, are stored. Some redistribution and reducing of the dislocation density at the grain boundaries and especially at triple junctions are observed. The distribution of the dislocations in the body of grains becomes more uniform.

The structural changes indicative of the return process in the grain boundaries are observed after annealing at $720 \mathrm{~K}$. As a result of the redistribution and annihilation of dislocations, the boundaries become more distinct, flat, with a smooth surface, i.e., are more equilibrium, indicating the significant decrease of the internal stresses level.

However, the heterogeneity of stresses distribution in the nanostructure is retained even after annealing at $800 \mathrm{~K}$, as evidenced by the non-uniformity of passing relaxation processes in volume of the material. As the polygonal boundaries so and the germs grains recrystallization of the size $\sim 30 \mathrm{~nm}$ were registered on the electron microscopic images. The several grown grains are detected (Fig. 3b).

Only after annealing at $870 \mathrm{~K}$ the initial recrystallization comprises the entire volume of the material (Fig. 3c). The formations of the new grains size up to $1 \mathrm{~cm}$ occur. The grains have the equiaxed shape, at the same time the structure inside the grains and the structure of the grain boundaries varies. The dislocation density within the grains does not exceed the value $\sim 10^{8} \mathrm{~cm}^{-2}$.

The changes of the nanocrystalline state after the annealings caused the evolution of the structure during the creep at $700 \mathrm{~K}$ (working temperature of the reactors), and the degree of resistance of plastic deformation.

After all treatments the samples of $\mathrm{Zr} 1 \mathrm{Nb}$ alloy were studied under creep conditions at $T=700 \mathrm{~K}$. The structures of the alloy $\mathrm{Zr1Nb}$, formed as a result of tests, are shown in Fig. 4.

The structural studies have shown that the nanostructure created by IPD rolling, proved to be unstable to subsequent mechanical-thermal actions in under the creep conditions at $700 \mathrm{~K}$ (Fig. 4a). Most of the boundaries were destroyed and in their place were formed the dislocation boundaries of polygon type. Sizes of polygons vary in the ranges of 50-150 $\mathrm{nm}$. The elongate boundaries with the large, above $\sim 20^{\circ}$, angles of disorientation were partially preserved. The transformation of the original structure is due to the activation of the return processes by climb of dislocations near the grain boundaries, and also by the processes of generation and annihilation of dislocations at the boundaries, which leads to their disintegration [11-14].

The heat treatments in the temperature range of $500-720 \mathrm{~K}$ do not destroy the deformation nanostructure, which is transformed in the process of creep, but it does not affect on the strength properties and the creep speed.

Qualitative changes in the deformation structure during the annealings with destruction of the nanostructured states lead to its sharp transformation in the process of creep. So, the processes of dynamic recrystallization during the creep at $700 \mathrm{~K}$ begin to develop in the structure obtained after 
annealing at $800 \mathrm{~K}$ and the new grains of size $0.1-0.5 \mathrm{mc}$ are formed (Fig. 4b).

The structure of $\mathrm{Zr} 1 \mathrm{Nb}$ alloy, completely recrystallized after annealing at $870 \mathrm{~K}$, was unstable under the creep conditions at $700 \mathrm{~K}$. The new grain boundaries were destroyed and clusters of dislocations with a tendency to formation of the cellular structure were formed (Fig. 4c).

Previously we have shown [11-14], that the plastic deformation in the conditions of creep the submicrograined and nanostructured $\mathrm{Zr}$ and alloy $\mathrm{Zr} 1 \mathrm{Nb}$, obtained with the use of IPD, take place due to the restructuring of the defected structure and it is accompanied by the stress relaxation. This process involves the destruction of the original structural configuration, created as a result of rolling, and the formation of the new structure, which is less stressful and more resistant to subsequent deformation. The cause of the kinetic instability of deformation structures is the change of the geometry of the plastic deformation and conditions of the temperatures-speed mode of deformation.

\section{Conclusions}

The performed treatments of alloy $\mathrm{Zr} 1 \mathrm{Nb}$ allowed obtaining the material in different structural states, the degree of resistance of which to the subsequent deformation in creep process at the temperature of $700 \mathrm{~K}$ is different.

The stress relaxation effect, while maintaining the nanostructured state, is observed after annealings at temperatures $500 \mathrm{~K}-720 \mathrm{~K}$, which does not lead to the noticeable change in the strength characteristics and structure of the alloy $\mathrm{Zr} 1 \mathrm{Nb}$ and may be the result of the redistribution of structural defects.

The heat treatments at the temperatures of $800 \mathrm{~K}-870 \mathrm{~K}$ qualitatively alters the structure of alloy, destroying the nanos- tructured state, that leads to the decreasing of the strength characteristics and to the increasing of the creep rate at $700 \mathrm{~K}$, due to instability of the formed structure and its transformation during deformation.

\section{References}

1. R.Z.Valiev, I.V.Aleksandrov, Nanostructure Materials Got an Intensive Plastic Deformation, Logos, Moscow (2000) [in Russian].

2. V.V.Rybin, Large Plastic Deformation and Fracture of Metals, Metallurgy, Moscow (1986) [in Russian].

3. P.Glensdorf, I.Pregogin, Thermodynamics Theory of Structures of Stability and Fluctuations, Mir, Moscow (1977), [in Russian].

4. V. Ebeling, Formation of structures at the irreversible processes, Mir, Moscow (1979), [in Russian].

5. R.Z.Valiev, Y.Estrin, Z.Horita et al., JOM, 58, 33 (2006).

6. A.P.Zhilyaev, T.G.Langdon, Progr. Mater. Sci., 53, 893 (2008).

7. V.M.Segal, I.J.Beyerlein, C.N.Tome et al., Fundamentals and Engineering of Severe Plastic Deformation, Nova Science Publ., New York (2010).

8. D.Duglus, Metallurgy of Zirconium, Atomic Publ., Moscow (1975) [in Russian].

9. I.I.Korobkov, Investigation of the Process Dynamic Deformational Aging in Zirconium Alloys, Metallurgy Publ., Moscow (1982) [in Russian].

10. J.D.Baird, Metals and Mater., 16, 18 (1971).

11. E.V.Karaseva, A.V.Matz, V.I.Sokolenko, V.A.Frolov, Probl. Atom. Sci. Techn., Ser.: "Vacuum, Pure Mater., Supercond.", 89, 106 (2014).

12. E.V.Karaseva, D.G.Malykhin, A.V.Matz, V.I.Sokolenko, Probl. Atom. Sci. Techn., Ser.: "Phys. Radiat. Effect and Radiat. Mater. Sci.", 74, 45 (2011).

13. E.V.Karaseva, V.I.Sokolenko, Probl. Atom. Sci. and Technology, Ser.: "Vacuum, Pure Mater., Supercond.", 89, 70 (2014).

14. E.V.Karaseva, Probl. Atom. Sci. and Technology, Ser.: "Phys. Radiat. Effect and Radiat. Mater. Sci.", 99, 130 (2015). 